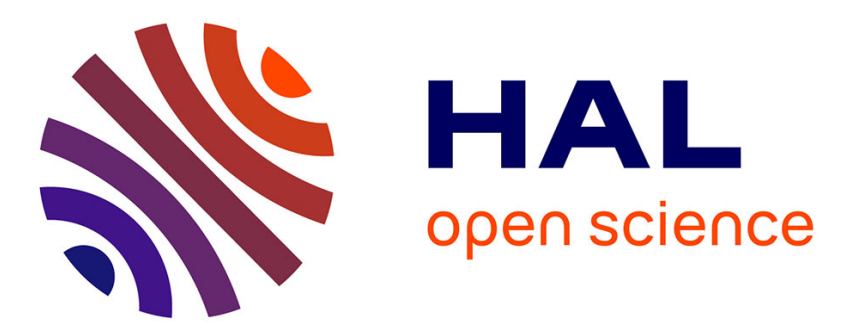

\title{
Effects of constant and fluctuating temperatures on the development of the solitary bee Osmia bicornis (Hymenoptera: Megachilidae)
}

\author{
Sabine Radmacher, Erhard Strohm
}

\section{- To cite this version:}

Sabine Radmacher, Erhard Strohm. Effects of constant and fluctuating temperatures on the development of the solitary bee Osmia bicornis (Hymenoptera: Megachilidae). Apidologie, 2011, 42 (6), pp.711-720. 10.1007/s13592-011-0078-9 . hal-01003615

\section{HAL Id: hal-01003615 https://hal.science/hal-01003615}

Submitted on 1 Jan 2011

HAL is a multi-disciplinary open access archive for the deposit and dissemination of scientific research documents, whether they are published or not. The documents may come from teaching and research institutions in France or abroad, or from public or private research centers.
L'archive ouverte pluridisciplinaire HAL, est destinée au dépôt et à la diffusion de documents scientifiques de niveau recherche, publiés ou non, émanant des établissements d'enseignement et de recherche français ou étrangers, des laboratoires publics ou privés. 


\title{
Effects of constant and fluctuating temperatures on the development of the solitary bee Osmia bicornis (Hymenoptera: Megachilidae)
}

\author{
Sabine RADMAChER, Erhard Strohm \\ Institute of Zoology, University of Regensburg, 93040 Regensburg, Germany \\ Received 9 December 2010 - Revised 11 February 2011 - Accepted 24 February 2011
}

\begin{abstract}
Since the temperature during development may affect growth and fitness in insects, climate change might affect important life history traits of solitary bees. We investigated the impact of three fluctuating and three constant temperature regimes on prepupal weight, mortality, and development time of Osmia bicornis. Prepupal weight decreased with increasing temperature, but not as strong under fluctuating conditions. Adult mortality increased in the warm treatments. Fluctuating (versus constant) temperatures accelerated development in the most stages and temperature regimes. The duration of almost all developmental phases decreased with increasing temperature, except for the prepupal phase that was prolonged in the warm treatments. The differences in thermal responses to fluctuating vs. constant temperatures illustrated the importance of fluctuating temperatures in studies investigating potential consequences of climate change for insects, including pollinators.
\end{abstract}

Osmia bicornis / temperature / development / climate change

\section{INTRODUCTION}

Temperature is one of the most important environmental factors for ectotherms and the temperature experienced during development strongly affects growth and many life history traits (Stillwell and Fox 2005; Steigenga and Fischer 2009), e.g. body size and development time (Ratte 1984; Atkinson 1994). In contrast to the well-known social honeybees that maintain a more or less constant temperature for their brood (e.g. Jones et al. 2004), most bee species are solitary (Michener 2000) and their offspring are largely exposed to the fluctuating ambient temperatures, at least in cavity-nesting species.

Corresponding author: S. Radmacher, sabine.radmacher@biologie.uni-regensburg.de Manuscript editor: Stan Schneider
In the course of the current climate change, overall mean temperatures are rising, spring (i.e. flowering) starts earlier, the growing season is prolonged, the intensity and frequency of weather extremes such as heat waves in summer are increasing - and these trends are predicted to progress (Menzel et al. 2006; Schwartz et al. 2006; IPCC 2007; EEA 2008). While some studies explored the potential consequences of climate change for herbivorous insects (e.g. Bale et al. 2002; Musolin et al. 2010), its direct impact on pollinators received little attention. The so-called "wild bees", including many solitary species, play an important role for the pollination of crops and natural plant populations (Freitas and Pereira 2004; Kremen 2008) and they are already declining due to habitat loss and fragmentation (e.g. Kearns et al. 1998). The impact of climate change on pollinators 
could aggravate this "pollinator crisis" and cause serious ecologic as well as economic consequences.

In this study, we investigated temperature influences on the development of the European fruit tree pollinator Osmia bicornis (Linnaeus 1758, Hymenoptera, Megachilidae, formerly Osmia rufa). The flight period of this abundant solitary and univoltine species usually ranges from early April to mid-June. Females build their linear nests in pre-existing cavities, provision the brood cells with pollen and some nectar and lay one egg per brood cell. The larvae hatch, consume the provision, spin a cocoon, go through a prepupal and pupal stage and finally eclose as adults in autumn. The development from oviposition to adult eclosion usually takes about 14-15 weeks (Raw 1972; Tasei 1973). The fully developed adults winter inside their cocoons and emerge the next spring.

In ectotherms, higher temperatures usually result in a shorter development time and smaller body size (Ratte 1984; Atkinson 1994). In the univoltine Osmia species, the accelerating effect of high temperatures on development combined with a prolonged growing season (due to climate change) could prolong the pre-wintering period (i.e. the period from adult eclosion inside the cocoon to the onset of wintering temperatures). A long pre-wintering period and small body size, however, had negative effects on survival and fitness in these bees (Tepedino and Torchio 1982; Bosch et al. 2000, 2010; Bosch and Kemp 2004; Bosch and Vicens 2006). Since the prepupal stage seems less susceptible to the negative effects of high temperatures than the adult stage, individuals developing under warm conditions might change the developmental pattern and prolong the prepupal stage (Kemp and Bosch 2005; Bosch et al. 2000, 2010).

Insects are usually adapted to fluctuating natural temperature conditions (see e.g. Beardmore 1960). However, most studies (including these about Osmia bees) that investigated temperature influences on development used constant temperatures, with no or only one fluctuating treatment for comparison (e.g. Bosch and Kemp 2000; Kemp and Bosch 2005; Radmacher and
Strohm 2010). The effects of fluctuating temperature regimes and the respective constant mean temperatures on development time have often been shown to differ, in many cases with an accelerating effect of fluctuating temperatures (Beck 1983; Ratte 1984). Therefore, the results of laboratory studies using constant temperatures can hardly be extrapolated to natural populations (Beck 1983). Thus, in order to estimate potential consequences of climate change for the respective species, the effects of fluctuating temperatures have to be taken into account.

The main objective of our study was to investigate the effect of both three fluctuating and the respective constant temperatures (cool, medium, warm) on body size, mortality, and the duration of development in O. bicornis. With regard to the ongoing climate change, we were particularly interested in whether the bees are affected by warmer temperatures or whether they are able to compensate possible negative effects.

\section{MATERIALS AND METHODS}

\subsection{Bees}

Brood cells were obtained from a free-flying $O$. bicornis population nesting in trap nests in an observation hut near the botanical garden of the University of Regensburg. The trap nests were made of dense styrofoam covered with transparent polycarbonate lids that allowed continuous observation of the nesting activity and brood development (for more details, see Strohm et al. 2002). These trap nests also allowed the separation of recently completed brood cells while the bee female continued nesting in the remaining part of this trap nest. During the peak nesting season (2-15 May) in 2008, we used 528 brood cells with 1-3 days old eggs from 62 nests for our investigations.

\subsection{Provision weight}

After separation from the nests, the brood cells were brought into the laboratory. The pollen 
provision with the attached egg was removed with a custom-made scoop to weigh it to the nearest $0.1 \mathrm{mg}$ (Sartorius analytic A120 S). Then the pollen loaf with the egg was carefully put back into its brood cell that was resealed with paper on the side and transparent foil on the top, both fixed with adhesive tape.

\subsection{Temperature treatments}

We used six temperature treatments as well as a control group (hut) to investigate possible temperature effects on the bee development. In the three fluctuating regimes, temperature followed a sine curve and reached the eponymous minimum and maximum values once in $24 \mathrm{~h}$. The cool, medium, and warm treatments were $10-25^{\circ} \mathrm{C}, 15-30^{\circ} \mathrm{C}$, and $20-35^{\circ} \mathrm{C}$. The three constant temperatures represented the mean temperatures of the fluctuating regimes: $17.5^{\circ} \mathrm{C}, 22.5^{\circ} \mathrm{C}$, and $27.5^{\circ} \mathrm{C}$.

The brood cells were randomly allocated to these seven temperature groups immediately after determination of provision weight. The sample sizes were: $N_{\text {hut }}=66, N_{17.5^{\circ} \mathrm{C}}=77, N_{22.5^{\circ} \mathrm{C}}=77$, $N_{27.5^{\circ} \mathrm{C}}=77, \quad N_{10-25^{\circ} \mathrm{C}}=77, N_{15-30^{\circ} \mathrm{C}}=76$, and $N_{20-35^{\circ} \mathrm{C}}=78$. For each group, brood cells were placed into a plastic box $(20 \times 20 \times 6 \mathrm{~cm})$ which was partly covered with plastic, partly with gauze to allow for ventilation. The plastic boxes were put into a cardboard box to prevent desiccation. The box of the control group was stored in the dark in the observation hut where the bees nested. The boxes of the treatment groups were stored in dark climate chambers (Ehret ATS 1373, Emmendingen, Germany, $\pm 1^{\circ} \mathrm{C}$ for constant temperatures; Binder KB 115, Tuttlingen, Germany, for fluctuating temperature regimes). Temperatures were monitored using thermobuttons (iButton DS1921G, Maxim Integrated Products, USA). All brood cells were checked daily for developmental stage and mortality of bee progeny.

We defined four visibly distinguishable developmental phases until the cocoon was finished: (1) egg phase (from egg laying to the beginning of feeding), (2) early consumption phase (from the beginning of feeding to the beginning of defecation), (3) defecation phase (from the beginning of defecation to the beginning of cocoon spinning), and (4) cocooning (from the beginning of cocoon spinning to the completely darkened cocoon). Ten to 14 days after cocoon completion, individual brood cells were opened, the cocoon was cleaned of faeces, weighed to the nearest $0.1 \mathrm{mg}$, placed in a new trap nest in the cardboard box, and put back in the according conditions. The weight of the cocoon with the prepupa inside is further referred to as "prepupal weight".

\subsection{Observation cocoons}

Since the cocoons of $O$. bicornis are opaque, we could not easily observe the development inside the cocoon. In order to check the development inside the cocoon without using the X-ray method (Stephen and Undurraga 1976), we cut a hole in the upper side of the cocoon (at least 1 week after cocoon completion to prevent spinning again and closing the spyhole). The holes were sealed with a transparent foil fixed with odourless superglue (UHU ${ }^{\circledR}$ Sekundenkleber, SUPERFLEX GEL). The spyhole allowed the daily monitoring of development inside the cocoon and the exact determination of the date of pupation and adult eclosion.

A sample of observation cocoons for every temperature treatment was prepared at the end of June $2008\left(N_{\text {hut }}=11, N_{17.5^{\circ} \mathrm{C}}=10, N_{22.5^{\circ} \mathrm{C}}=11\right.$, $N_{27.5^{\circ} \mathrm{C}}=15, \quad N_{10-25^{\circ} \mathrm{C}}=10, N_{15-30^{\circ} \mathrm{C}}=15$, and $\left.N_{20-35^{\circ} \mathrm{C}}=15\right)$. Since some bees were already in the pupal stage at this time, their exact date of pupation could not be recorded. Such observation cocoons were excluded from all analyses except in the $15-30^{\circ} \mathrm{C}$ group where they were included for the calculation of the duration of complete development. The duration of the prepupal and pupal stage had to be estimated based on only two individuals in this group, since these bees entered the pupal stage unexpectedly early.

\subsection{Wintering}

All cocoons were transferred to a climate chamber with constant $4^{\circ} \mathrm{C}$ on 2 October 2008. On 18 March 2009 , the cocoons were placed in transparent plastic containers (with gauze-covered windows for ventilation) and transferred to the hut where they experienced the natural temperature increase and emerged in spring. In the middle of May, all failed cocoons were opened and inspected for mortality stage. Some cocoons/bees from each temperature treatment were used for other 
investigations during wintering, therefore we used the remaining cocoon number as reference $(=100 \%)$ for the determination of mortality for the stages inside the cocoon.

\subsection{Data analyses}

Since the body size of $O$. bicornis depends largely on the provision weight (Radmacher and Strohm 2010), we used the ratio of prepupal weight to provision weight as a measure for body size to correct for individual differences in provision weight. ANOVAs (PASW Statistics 18 (i.e. SPSS 18.0)) with temperature level (cool, medium, and warm) and temperature mode (constant and fluctuating) as fixed factors were used to test for effects of temperature level and mode on the duration of all recorded developmental stages, on the duration of complete development, and on the prepupal weight. The control group (hut) was not included in the statistical analyses but is presented in the figures as a reference for development under natural conditions. Mortality rates were analysed with logistic regressions with survival status (dead or alive) in the respective stage as dependent variable and temperature level as well as temperature mode (categorised) as covariates (PASW Statistics 18).

\section{RESULTS}

\subsection{Prepupal weight}

There was a significant effect of temperature level and temperature mode on the ratio of prepupal weight to provision weight (temperature level: $F=137.8, d f=2, P<0.001$; temperature mode: $F=325.8, d f=1, P<0.001)$. Higher temperatures resulted in lower prepupal weights and fluctuating temperatures tended to result in higher prepupal weights than the constant mean temperatures (Figure 1). There was a significant interaction between temperature level and mode indicating that the decrease in weight ratio with increasing temperatures was smaller under fluctuating conditions (Figure 1; temperature level $\mathrm{x}$ temperature mode: $F=69.9, d f=2, P<0.001)$. Concerning the constant temperatures, the $22.5^{\circ} \mathrm{C}$ treatment deviated from the general trend in that the prepupal weights were comparatively (and unusually) low.

\subsection{Mortality}

The mortality data are given in Table I. Egg to cocoon mortality and pupal mortality were neither influenced by temperature level (egg to cooon: Wald $=1.728, d f=1, P=0.189$; pupa: Wald $=0.227, d f=1, P=0.634$ ) nor by temperature mode (egg to cocoon: Wald $=0.125, d f=1$, $P=0.724$; pupa: Wald $=1.014, d f=1, P=0.314$ ). Prepupal mortality was affected by temperature mode (Wald $=10.103, d f=1, P=0.001$ ), but not by temperature level (Wald $=0.324, d f=1, P=0.569$ ) with unusually high mortality in $15-30^{\circ} \mathrm{C}$. Adult mortality was very high in the warm treatments $\left(27.5\right.$ and $\left.20-35^{\circ} \mathrm{C}\right)$ and significantly influenced by both temperature level (Wald $=94.511, d f=1$, $P<0.001$ ) and temperature mode (Wald $=22.18$, $d f=1, P<0.001)$.

\subsection{Duration of development}

Generally, the duration of all four developmental phases until cocoon completion decreased with increasing temperature, except for the defecation phase in $22.5^{\circ} \mathrm{C}$ that was anomalously long (Figure 2; egg phase: $F=1530.9, d f=2$, $P<0.001$; early consumption phase: $F=1779.1$, $d f=2, \quad P<0.001$, defecation phase: $F=246.02$, $d f=2, \quad P<0.001$; cocooning: $F=66.7, d f=2$, $P<0.001$ ). Fluctuating (vs. constant) conditions had a significant accelerating effect on the early consumption phase $(F=27.6, d f=1, P<0.001)$, the defecation phase $(F=936.2, d f=1, P<0.001)$, and cocooning $(F=16.84, d f=1, P<0.001)$, but not on the egg phase $(F=2.99, d f=1, P=0.085)$.

The duration of the prepupal stage was significantly influenced by temperature level $(F=17.37, d f=2, \quad P<0.001)$ and temperature mode $(F=16.54, d f=1, P<0.001)$. While the accelerating effect of fluctuating (vs. constant) temperatures followed the general pattern found in the other developmental stages, the observed effect of temperature level was converse to all 


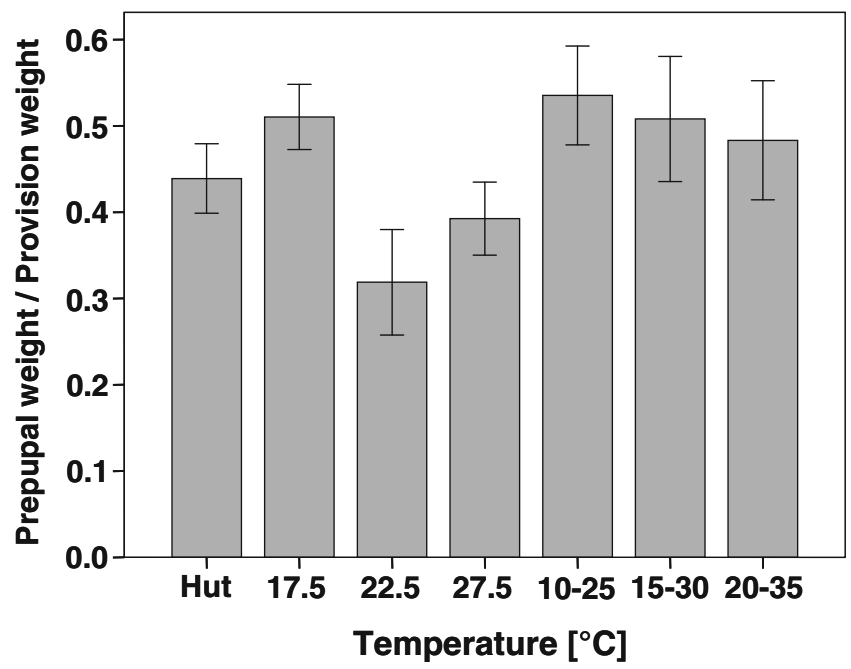

Figure 1. Ratio of prepupal weight to provision weight (mean $\pm \mathrm{SD})$ as a measure for body size of $O$. bicornis offspring reared at three constant $\left(N_{17.5^{\circ} \mathrm{C}}=70, N_{22.5^{\circ} \mathrm{C}}=67\right.$, and $\left.N_{27.5^{\circ} \mathrm{C}}=74\right)$ and three fluctuating $\left(N_{10-25^{\circ} \mathrm{C}}=73\right.$, $N_{15-30^{\circ} \mathrm{C}}=66$, and $\left.N_{20-35^{\circ} \mathrm{C}}=74\right)$ temperature regimes. The control group $\left(N_{\mathrm{Hut}}=58\right)$ was exposed to natural temperature conditions.

other investigated developmental stages since the duration of the prepupal stage increased considerably in the warm treatments (Figure 3). Consistent with the general pattern, the duration of the pupal stage decreased with increasing temperature $(F=157, d f=2, P<0.001)$, but there was no significant effect of temperature mode $(F=3.489$, $d f=1, P=0.069)$ in this stage (Figure 3 ).
We found a significant effect of temperature level $(F=73.9, d f=2, P<0.001)$ and temperature mode $(F=42.43, d f=1, P<0.001)$ on the duration of complete development from egg to adult eclosion. There was a general decrease in duration with increasing temperature, however, the difference between the medium and the warm temperature treatments

Table I. Mortality rates of $O$. bicornis offspring reared at seven different temperature treatments (three constant temperatures: $17.5^{\circ} \mathrm{C}, 22.5^{\circ} \mathrm{C}$, and $27.5^{\circ} \mathrm{C}$; three fluctuating temperature regimes: $10-25^{\circ} \mathrm{C}, 15-30^{\circ} \mathrm{C}$, and 20 $35^{\circ} \mathrm{C}$; hut $=$ natural temperature conditions).

\begin{tabular}{lcccccc}
\hline Treatment & $\begin{array}{c}\text { Brood } \\
\text { cells } N\end{array}$ & $\begin{array}{c}\text { Egg cocoon } \\
\text { mortality (\%) }\end{array}$ & $\begin{array}{c}\text { Cocoons } \\
N\end{array}$ & $\begin{array}{c}\text { Prepupa } \\
\text { mortality (\%) }\end{array}$ & $\begin{array}{c}\text { Pupa } \\
\text { mortality (\%) }\end{array}$ & $\begin{array}{c}\text { Adult } \\
\text { mortality (\%) }\end{array}$ \\
\hline Hut & 66 & 9.1 & 46 & 0 & 0 & 0 \\
$17.5^{\circ} \mathrm{C}$ & 77 & 9.1 & 56 & 1.8 & 0 & 16.1 \\
$22.5^{\circ} \mathrm{C}$ & 77 & 13.0 & 53 & 0 & 1.9 & 24.5 \\
$27.5^{\circ} \mathrm{C}$ & 77 & 1.3 & 74 & 0 & 0 & 100.0 \\
$10-25^{\circ} \mathrm{C}$ & 77 & 5.2 & 59 & 3.4 & 0 & 0 \\
$15-30^{\circ} \mathrm{C}$ & 76 & 10.5 & 52 & 26.9 & 3.8 & 1.9 \\
$20-35^{\circ} \mathrm{C}$ & 78 & 5.2 & 65 & 9.2 & 1.5 & 86.2 \\
\hline
\end{tabular}

Percentage values refer to the given sample sizes of brood cells or cocoons, respectively 


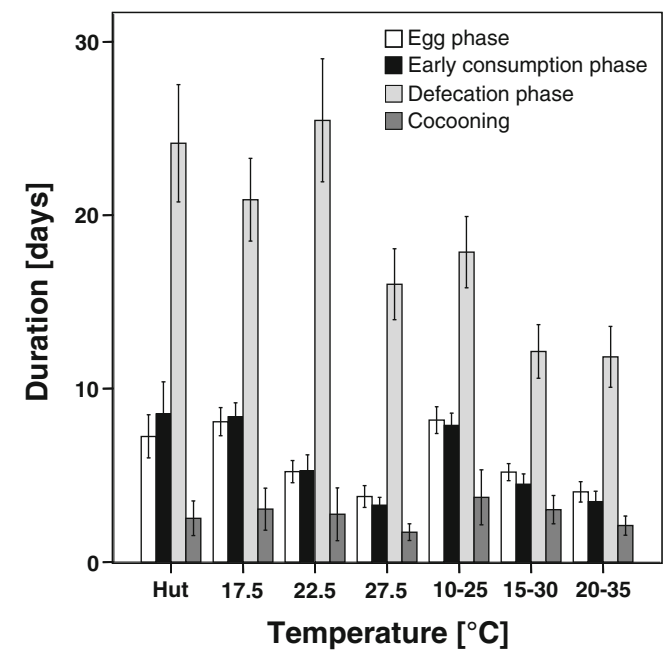

Figure 2. Duration (mean $\pm \mathrm{SD}$ ) of four visibly distinguishable developmental phases (egg phase, early consumption phase, defecation phase, and cocooning) from egg to cocoon completion of $O$. bicornis offspring reared at seven different temperature regimes (control: $N_{\text {Hut }}=58$; constant temperatures: $N_{17.5^{\circ} \mathrm{C}}=70, N_{22.5^{\circ} \mathrm{C}}=67$, and $N_{27.5^{\circ} \mathrm{C}}=74$; fluctuating temperature regimes: $N_{10-25^{\circ} \mathrm{C}}=73$, $N_{15-30^{\circ} \mathrm{C}}=66$, and $\left.N_{20-35^{\circ} \mathrm{C}}=74\right)$.

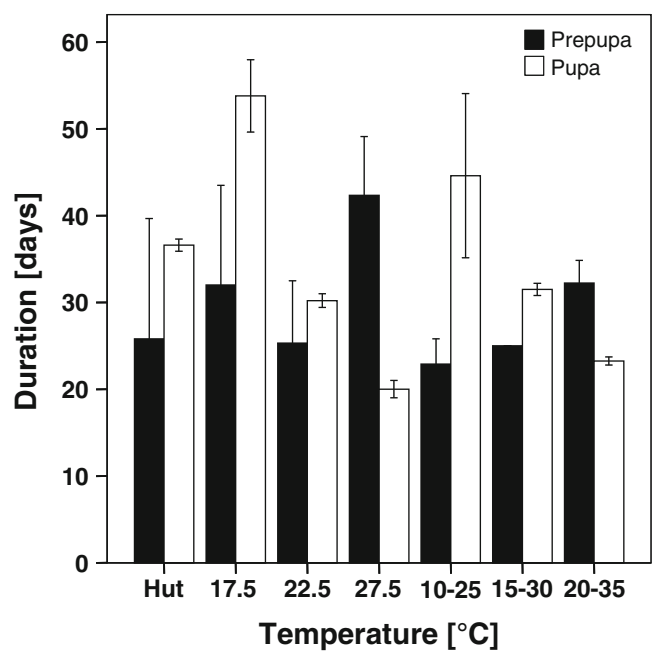

Figure 3. Duration (mean $\pm \mathrm{SD}$ ) of the prepupal and the pupal stage of $O$. bicornis offspring reared at seven different temperature regimes (control: $N_{\mathrm{Hut}}=10$; constant temperatures: $N_{17.5^{\circ} \mathrm{C}}=10, N_{22.5^{\circ} \mathrm{C}}=10$, and $N_{27.5^{\circ} \mathrm{C}}=9$; fluctuating temperature regimes: $N_{10-25^{\circ} \mathrm{C}}=10, N_{15-30^{\circ} \mathrm{C}}=2$, and $\left.N_{20-35^{\circ} \mathrm{C}}=8\right)$. was small (Figure 4). Fluctuating (vs. constant) conditions led to an acceleration of development. Though no significant interaction of temperature level and temperature mode was detected $(F=1.134, d f=2, P=0.33)$, the accelerating effect of fluctuating conditions tended to decrease with increasing temperature (Figure 4).

\section{DISCUSSION}

\subsection{Prepupal weight}

In general, our results on the effects of temperature on prepupal weight are consistent with the temperature-size rule (Atkinson 1994) and a previous study on O. bicornis which revealed a strong decrease in body size with increasing constant rearing temperatures (Radmacher and Strohm 2010). However, bee offspring in the $22.5^{\circ} \mathrm{C}$ treatment had an unexpectedly low prepupal weight. Taking into account a comparatively frequent occurrence of pollen remnants in the brood cells and the anomalously long defecation phase, the conditions might have been somehow suboptimal in this treatment. We were not able to explain this finding since the $22.5^{\circ} \mathrm{C}$ treatment was treated in the same way as the others. Regarding the $17.5^{\circ} \mathrm{C}$ and $27.5^{\circ} \mathrm{C}$ treatment, the decrease in body weight was not as pronounced as in a previous study (Radmacher and Strohm 2010), where overall warmer temperatures $\left(20^{\circ} \mathrm{C}, 25^{\circ} \mathrm{C}\right.$, and $\left.30^{\circ} \mathrm{C}\right)$ were used and the weight of adult bees inside their cocoons was determined.

Under fluctuating conditions, the bee offspring attained higher prepupal weights than in the respective constant mean temperatures and the decrease in prepupal weight with increasing temperature was considerably smaller than in the constant treatments. These findings support the view that the results of studies conducted with constant temperatures in the laboratory can hardly be extrapolated to populations living under natural fluctuating conditions (Beck 1983; Ratte 1984). Moreover, our results 


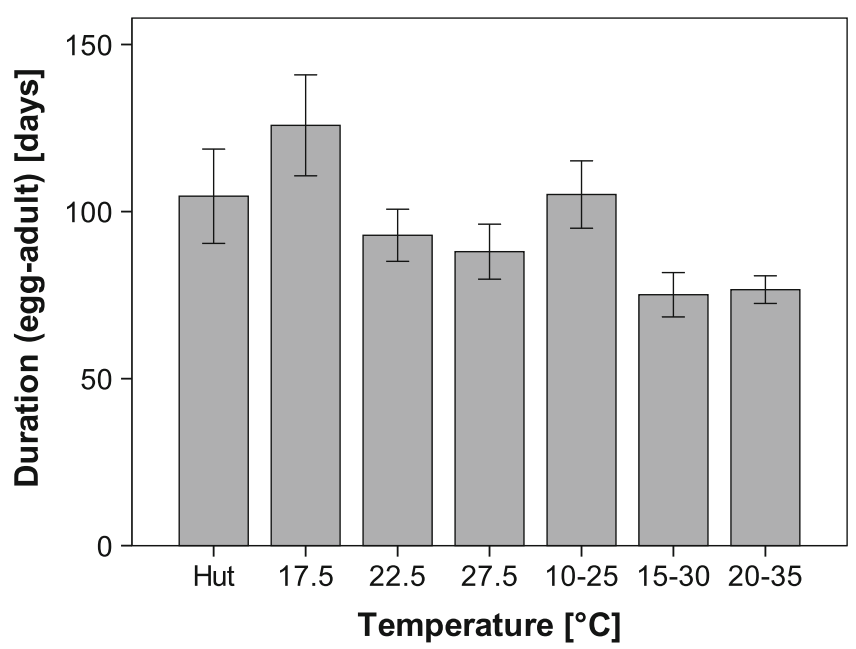

Figure 4. Duration (mean $\pm \mathrm{SD}$ ) of complete development (from egg to adult eclosion) of $O$. bicornis offspring reared at seven different temperature regimes (control: $N_{\mathrm{Hut}}=10$; constant temperatures: $N_{17.5^{\circ} \mathrm{C}}=10, N_{22.5^{\circ} \mathrm{C}}=10$, and $N_{27.5^{\circ} \mathrm{C}}=9$; fluctuating temperature regimes: $N_{10-25^{\circ} \mathrm{C}}=10, N_{15-30^{\circ} \mathrm{C}}=9$, and $N_{20-35^{\circ} \mathrm{C}}=8$ ).

suggest that under fluctuating conditions an overall warming of several degrees during development would probably have only a small negative effect on the prepupal weight in $O$. bicornis. However, weight loss can be considerable in the pupal, pre-wintering, and wintering phases (Bosch and Vicens 2002; Sgolastra et al. 2010). Therefore, warming during the entire life cycle could have stronger effects on final body weight.

\subsection{Mortality}

The rates of mortality from egg to cocoon and in the pupal stage were not influenced by temperature level or temperature mode and they were within the usual range for this species (see the hut group Table I, Strohm et al. 2002). We suppose that the significant effect of temperature mode on prepupal mortality and the comparatively high prepupal mortality in the $15-30^{\circ} \mathrm{C}$ treatment were probably caused by a mould infestation that apparently occurred only in the $15-30^{\circ} \mathrm{C}$ and $20-35^{\circ} \mathrm{C}$ treatment at the beginning of June 2008. Therefore, we assume that mortality until the adult stage was not severely affected by developmental temperature.
In contrast, mortality in the adult stage increased considerably with increasing temperature. Though mortality rates were generally lower under fluctuating than under constant temperature conditions, adult mortality was very high in the $20-35^{\circ} \mathrm{C}$ treatment. Since all bees were transferred to $4^{\circ} \mathrm{C}$ when the slowest group $\left(17.5^{\circ} \mathrm{C}\right)$ had completed their development, particularly the bees in the warm treatments experienced a long pre-wintering period (about 60-70 days) in high temperatures that probably caused the very high adult mortality due to fat body depletion (Bosch et al. 2000, 2010; Bosch and Kemp 2004). The length of the prewintering period was similar for the bees in the warm and in the medium temperature treatments; however, the bees in the medium treatments were exposed to lower temperatures during this time. The medium temperatures seemed to be less harmful than the warm temperatures, particularly under fluctuating conditions. For comparison, bees under natural conditions (hut) experienced a pre-wintering period of 46 days on average in $17.0 \pm 7.8^{\circ} \mathrm{C}$ (mean $\pm \mathrm{SD}$ ). The elevated adult mortality in the $17.5^{\circ} \mathrm{C}$ treatment $(16.1 \%$; compared to $0 \%$ in $10-25^{\circ} \mathrm{C}$ and in the control) was possibly caused by a too short pre-wintering period. 
Since the $17.5^{\circ} \mathrm{C}$ group was transferred to $4^{\circ} \mathrm{C}$ shortly after we had observed the last adult eclosion, the pre-wintering period might have been too short for some individuals to lower the respiration rate to an appropriate level for wintering (Bosch et al. 2010).

Our results for adult mortality underlined the importance of the duration of and the temperature during the pre-wintering phase for the survival and fitness of Osmia bees (Bosch and Kemp 2004). However, even with ongoing climate change it seems unlikely that in the foreseeable future natural $O$. bicornis populations will be exposed to such warm prewintering temperatures as we used for our warm treatments. Due to the low adult mortality in the fluctuating $15-30^{\circ} \mathrm{C}$ treatment, we tentatively suggest that climate change would probably not have a strong negative effect on the survival of $O$. bicornis during the pre-wintering phase.

\subsection{Duration of development}

For most (but not all) of the recorded developmental stages and the complete development, we found a significant acceleration in the fluctuating versus the corresponding constant temperature treatments. Regarding complete development, the accelerating effect of temperature fluctuations tended to decrease with increasing temperature, even though this trend was not significant. A similar pattern was found in mosquitoes (Joshi 1996). These findings are generally consistent with the often observed pattern that for a certain insect species temperature fluctuations in the range below a certain temperature may cause an acceleration of development, while the converse is true for fluctuations near the temperature optimum (Beck 1983; Hagstrum and Milliken 1991). However, not all insect species follow this pattern (see, e.g. Neumann and Heimbach 1975; Welbers 1975). While we did not detect a deceleration due to fluctuating temperatures in our warm treatments, such an effect might occur at temperatures higher than used in this study. The congeneric Osmia lignaria developed faster in two fluctuating treatments $\left(14: 27^{\circ} \mathrm{C}\right.$ and orchard) than in equivalent constant temperatures $\left(22\right.$ and $18^{\circ} \mathrm{C}$, respectively; Bosch and Kemp 2000), but no warmer fluctuating regime was investigated.

Development time of ectotherms typically decreases with increasing temperature (up to an optimal temperature) due to the acceleration of biochemical processes at higher temperatures (Ratte 1984; Atkinson 1996). However, the effect of temperature on development time has been shown to differ among species, populations, and developmental stages of a species (Ratte 1984; Ayres and Scriber 1994; Bosch and Kemp 2000; Rombough 2003; Kemp and Bosch 2005; Folguera et al. 2010). We found the typical decrease of development time with increasing temperatures in almost all investigated developmental stages of $O$. bicornis - except in the prepupal stage whose duration increased in the warm treatments.

Based only on the data in this study, we cannot completely exclude that this extension of the prepupal stage could be a sign of harmful but not yet lethal temperature. However, Osmia bees probably undergo a summer diapause in the prepupal stage (Kemp et al. 2004; Bosch et al. 2010) that seems to be the developmental stage with the highest plasticity with regard to duration and with a lower susceptibility to warm temperatures than the adult stage (Sgolastra 2007; Bosch and Kemp 2000; Bosch et al. 2000, 2010). Our results are consistent with Kemp and Bosch (2005) who found a U-shaped thermal response of the prepupal stage in $O$. lignaria with increasing duration below and above a certain medium temperature and we assent to their assumption that prolonging the prepupal phase could be a suitable mechanism to adjust adult eclosion date to the onset of colder temperatures in autumn if development was accelerated due to hot summers (Kemp and Bosch 2005; Bosch et al. 2010). This adjustment seems to be very important to avoid long pre-wintering periods with their negative effects on survival and fitness (Bosch and Kemp 2004; Bosch et al. 2010, and see Section 4.2). The similar duration of complete development in the medium and warm treatments (Figure 4) sug- 
gests that the acceleration of the larval and pupal development due to high temperature was largely compensated by the prolonged prepupal phase. Whether the observed extension of the prepupal period was triggered by the actual temperature in the prepupal phase or by the temperature experienced earlier in development cannot be decided based on our data (but see Kemp and Bosch 2005). However, the observed developmental plasticity in the duration of the prepupal stage might help $O$. bicornis to cope with the increasing frequency of heat waves in summer and the overall elevated temperatures due to climate change.

\section{ACKNOWLEDGEMENTS}

We thank two anonymous reviewers for their constructive comments and suggestions on an earlier draft of this manuscript. We gratefully acknowledge financial support for Sabine Radmacher from the Universität Bayern e.V. through a Ph.D. fellowship.

Effets de températures constantes et fluctuantes sur le développement de l'abeille solitaire Osmia bicornis (Hymenoptera: Megachilidae)

Osmia bicornis / température / développement / changement climatique

Auswirkungen von konstanten und fluktuierenden Temperaturen auf die Entwicklung der solitären Biene Osmia bicornis (Hymenoptera; Megachilidae)

\section{Osmia bicornis / Temperatur / Entwicklung / Klimawandel}

\section{REFERENCES}

Atkinson, D. (1994) Temperature and organism size-a biological law for ectotherms? Adv. Ecol. Res. 25, 1-58

Atkinson, D. (1996) Ectotherm life history responses to developmental temperature. In: Johnston, I.A., Bennett, A.F. (eds.) Animals and temperature. Phenotypic and evolutionary adaption, pp. 183-204. Cambridge University Press, Cambridge
Ayres, M.P., Scriber, J.M. (1994) Local adaptation to regional climates in Papilio canadensis (Lepidoptera, Papilionidae). Ecol. Monogr. 64(4), 465-482

Bale, J.S., Masters, G.J., Hodkinson, I.D., Awmack, C., Bezemer, T.M., Brown, V.K., Butterfield, J., Buse, A., Coulson, J.C., Farrar, J., Good, J.E.G., Harrington, R., Hartley, S., Jones, T.H., Lindroth, R.L., Press, M.C., Symrnioudis, I., Watt, A.D., Whittaker, J.B. (2002) Herbivory in global climate change research: direct effects of rising temperature on insect herbivores. Glob. Change Biol. 8(1), 1-16

Beardmore, J.A. (1960) Developmental stability in constant and fluctuating temperatures. Heredity 14 (3/4), 411-422

Beck, S.D. (1983) Insect thermoperiodism. Annu. Rev. Entomol. 28, 91-108

Bosch, J., Kemp, W.P. (2000) Development and emergence of the orchard pollinator Osmia lignaria (Hymenoptera: Megachilidae). Environ. Entomol. 29(1), 8-13

Bosch, J., Kemp, W.P. (2004) Effect of pre-wintering and wintering temperature regimes on weight loss, survival, and emergence time in the mason bee Osmia cornuta (Hymenoptera: Megachilidae). Apidologie 35(5), 469-479

Bosch, J., Vicens, N. (2002) Body size as an estimator of production costs in a solitary bee. Ecol. Entomol. 27 (2), 129-137

Bosch, J., Vicens, N. (2006) Relationship between body size, provisioning rate, longevity and reproductive success in females of the solitary bee Osmia cornuta. Behav. Ecol. Sociobiol. 60(1), 26-33

Bosch, J., Kemp, W.P., Peterson, S.S. (2000) Management of Osmia lignaria (Hymenoptera: Megachilidae) populations for almond pollination: methods to advance bee emergence. Environ. Entomol. 29(5), 874-883

Bosch, J., Sgolastra, F., Kemp, W.P. (2010) Timing of eclosion affects diapause development, fat body consumption and longevity in Osmia lignaria, a univoltine, adult-wintering solitary bee. J. Insect Physiol. 56(12), 1949-1957

EEA (2008) European Environmental Agency, Impacts of Europe's changing climate-2008 indicator-based assessment, EEA report no. 4. http://www.eea. europa.eu/publications/eea_report_2008_4.

Folguera, G., Mensch, J., Munoz, J.L., Ceballos, S.G., Hasson, E., Bozinovic, F. (2010) Ontogenetic stagedependent effect of temperature on developmental and metabolic rates in a holometabolous insect. J. Insect Physiol. 56(11), 1679-1684

Freitas, B.M., Pereira, J.O.P. (2004) Solitary bees: conservation, rearing and management for pollination. Universidade Federal do Ceará, Ceará, Brazil

Hagstrum, D.W., Milliken, G.A. (1991) Modeling differences in insect developmental times between constant and fluctuating temperatures. Ann. Entomol. Soc. Am. 84(4), 369-379 
IPCC (2007) Intergovernmental Panel on Climate Change, Fourth Assessment Report (AR4): Climate Change 2007. IPCC Secreteriat, Genf

Jones, J.C., Myerscough, M.R., Graham, S., Oldroyd, B. P. (2004) Honey bee nest thermoregulation: diversity promotes stability. Science 305(5682), 402-404

Joshi, D.S. (1996) Effect of fluctuating and constant temperatures on development, adult longevity and fecundity in the mosquito Aedes krombeini. J. Therm. Biol. 21(3), 151-154

Kearns, C.A., Inouye, D.W., Waser, N.M. (1998) Endangered mutualisms: the conservation of plant-pollinator interactions. Annu. Rev. Ecol. Syst. 29(1), 83-112

Kemp, W.P., Bosch, J. (2005) Effect of temperature on Osmia lignaria (Hymenoptera: Megachilidae) prepupa-adult development, survival, and emergence. J. Econ. Entomol. 98(6), 1917-1923

Kemp, W.P., Bosch, J., Dennis, B. (2004) Oxygen consumption during the life cycles of the prepupawintering bee Megachile rotundata and the adultwintering bee Osmia lignaria (Hymenoptera: Megachilidae). Ann. Entomol. Soc. Am. 97(1), 161-170

Kremen, C. (2008) Crop pollination services from wild bees. In: James, R.R., Pitts-Singer, T.L. (eds.) Bee pollination in agricultural ecosystems, pp. 10-26. Oxford University Press, Inc., Oxford

Menzel, A., Sparks, T.H., Estrella, N., Koch, E., Aasa, A., Ahas, R., Alm-Kubler, K., Bissolli, P., Braslavska, O., Briede, A., Chmielewski, F.M., Crepinsek, Z., Curnel, Y., Dahl, A., Defila, C., Donnelly, A., Filella, Y., Jatcza, K., Mage, F., Mestre, A., Nordli, O., Penuelas, J., Pirinen, P., Remisova, V., Scheifinger, H., Striz, M., Susnik, A., Van Vliet, A.J.H., Wielgolaski, F.E., Zach, S., Zust, A. (2006) European phenological response to climate change matches the warming pattern. Glob. Change Biol. 12(10), 1969-1976

Michener, C.D. (2000) The bees of the world. The John Hopkins University Press, Baltimore

Musolin, D.L., Tougou, D., Fujisaki, K. (2010) Too hot to handle? Phenological and life-history responses to simulated climate change of the southern green stink bug Nezara viridula (Heteroptera: Pentatomidae). Glob. Change Biol. 16(1), 73-87

Neumann, D., Heimbach, F. (1975) Das Wachstum des Kohlweißlings bei konstanten und tagesperiodisch wechselnden temperaturen. Oecologia 20(2), 135-141

Radmacher, S., Strohm, E. (2010) Factors affecting offspring body size in the solitary bee Osmia bicornis
(Hymenoptera, Megachilidae). Apidologie 41(2), 169-177

Ratte, H.T. (1984) Temperature and insect development. In: Hoffmann, K.H. (ed.) Environmental physiology and biochemistry of insects, pp. 33-66. Springer, Berlin

Raw, A. (1972) The biology of the solitary bee Osmia rufa (L.) (Megachilidae). Trans. R. Entomol. Soc. Lond. 124(3), 213-229

Rombough, P. (2003) Modelling developmental time and temperature. Nature 424(6946), 268-269

Schwartz, M.D., Ahas, R., Aasa, A. (2006) Onset of spring starting earlier across the Northern Hemisphere. Glob. Change Biol. 12(2), 343-351

Sgolastra, F. (2007). Ecofisiologia del ciclo biologico di Osmia lignaria (Hymenoptera: Megachilidae). Unpublished doctoral dissertation, Facolta' di agraria, Università di Bologna.

Sgolastra, F., Bosch, J., Molowny-Horas, R., Maini, S., Kemp, W.P. (2010) Effect of temperature regime on diapause intensity in an adult-wintering Hymenopteran with obligate diapause. J. Insect Physiol. 56(2), 185-194

Steigenga, M.J., Fischer, K. (2009) Fitness consequences of variation in developmental temperature in a butterfly. J. Therm. Biol. 34(5), 244-249

Stephen, W.P., Undurraga, J.M. (1976) X-radiography, an analytical tool in population studies of the leafcutter bee Megachile pacifica. J. Apic. Res. 15(2), 81-87

Stillwell, R.C., Fox, C.W. (2005) Complex patterns of phenotypic plasticity: interactive effects of temperature during rearing and oviposition. Ecology 86(4), 924-934

Strohm, E., Daniels, H., Warmers, C., Stoll, C. (2002) Nest provisioning and a possible cost of reproduction in the megachilid bee Osmia rufa studied by a new observation method. Ethol. Ecol. Evol. 14(3), 255-268

Tasei, J.N. (1973) Observations sur le développement d'Osmia cornuta Latr. et Osmia rufa L. (Hymenoptera Megachilidae). Apidologie 4(4), 295-315

Tepedino, V.J., Torchio, P.F. (1982) Phenotypic variability in nesting success among Osmia lignaria propinqua females in a glasshouse environment: (Hymenoptera: Megachilidae). Ecol. Entomol. 7(4), 453-462

Welbers, P. (1975) Der Einfluß von tagesperiodischen Wechseltemperaturen bei der Motte Pectinophora. Oecologia 21(1), 31-42 